\title{
Differentiated Instruction in a Calculus Curriculum for College Students in Taiwan
}

\author{
Jing-Hua Chen ${ }^{1} \&$ Yi-Chou Chen ${ }^{1}$ \\ ${ }^{1}$ General Education Center, Army Academy R. O. C., Taiwan \\ Correspondence: Jing-Hua Chen, General Education Center, Army Academy R. O. C., No. 750, Longdong Rd., \\ Zhongli Dist., Taoyuan City 320, Taiwan. Tel: 886-3-437-2313. E-mail: v88n90@gmail.com
}

Received: August 25, 2017

Accepted: September 20, 2017

Online Published: October 28, 2017

doi:10.5539/jel.v7n1p88

URL: https://doi.org/10.5539/jel.v7n1p88

This research was partially supported by grant from MOST 105-2511-S-539-001 Ministry of Science and Technology, Taiwan.

\begin{abstract}
Objectives: To explore differentiated instruction within a calculus curriculum. For college students to learn concentration, motivation and the impact of academic achievement; explore the attitudes and ideas of students on differentiated instruction within a calculus curriculum; build up the diversity of mathematics education within varied educational settings. Participants: Sample data were collected from freshman students of the Army Academy: total sample $=60$, experimental and control group each had 30. Methods: Quasi-experimental design. Study tested whether differentiated instruction would enhance calculus instruction, compared with a traditional teaching method. Results: As hypothesized, results showed a significant difference in calculus achievement between experimental and control groups. Conclusions: Results supported the effectiveness of differentiated instruction on calculus curriculum. Finally, depending on the research results, the researcher provided practical suggestions for the educational research.
\end{abstract}

Keywords: academic achievement, differentiated instruction, calculus, Taiwan

\section{Introduction}

The Ministry of Education in Taiwan (Ministry of Education, 2015), in response to the implementation of the 12-year Compulsory Education, takes the "achievement of every child" as a prerequisite. To meet the demand of diversified learning, struggling students will receive remedial teaching through differentiated instruction. Differentiated instruction serves the same purpose with Confucius in teaching students according to their aptitude. In Taiwan, the study of differentiated instruction is scarce. All of the differentiated instruction case studies are mostly conducted in the field of mathematics. Virtually no research has been conducted on college students.

At present, in Taiwan's higher education, students with multiple admission to enter the university. First-year college students with largely different levels of ability are placed in the classroom for basic courses such as Chinese, English language, and mathematics, among others. Taking the Army Academy college students as an example, the students are from high schools, senior vocational schools and comprehensive high schools. They differ for ability in mathematics. Therefore, the present study constructed the program of a calculus course for students according to their need.

Throughout the current study of higher education in Taiwan, little attention is paid to the issue of differentiated instruction research. This study attempts to construct a differential program of calculus, which aims to improve student learning motivation, learning satisfaction, and learning outcomes. The purpose of the study is:

1) Exploring differentiated instruction to understand the students' learning style, difficulties, and motivation in order to enhance the students' academic achievement and learning satisfaction.

2) According to study results, explore the impact of differentiated instruction on calculus for students, and design more suitable content for mathematics education through differentiation that will improve students learning efficacy. 


\subsection{The Differentiated Instruction}

Differentiated instruction means that teachers can adjust the teaching content, progress and evaluation methods according to individual differences and needs of the students, so as to enhance students' learning effect and guide students' adaptive development ( $\mathrm{Wu}, 2012)$.

Differentiation is a pedagogical, not an organizational approach (Stradling \& Saunders, 1993). It is a way that teachers modify teaching and learning routines to meet the needs of students' readiness levels, interests, and modes of learning (Tomlinson, 1999, 2001). Differentiation can be defined as an approach to teaching in which teachers modify the curriculum, teaching methods, resources, learning activities, and student outcomes to address the diverse needs of each student and small groups of students to maximize the learning opportunity for each student in a classroom (Bearne, 1996; Tomlinson, 1999). Differentiated instruction is the teacher in a classroom in a multivariate way who can interpret teaching content, teaching process and teaching products (Middendorf, 2009).

Educators recognize that students have different abilities, interests, readiness, learning styles, and personalities. Therefore, educators can meet the needs of all students and help them to meet and exceed established standards through the use of differentiated instruction strategies (Levy, 2008; Tomlinson, 2008).

Tomlinson (1999) proposed building a conceptual map of differentiated classrooms (Figure 1). The characteristics of effective differentiation are (1) curriculum and instruction are proactive, not reactive; (2) flexible use of small teaching-leaning groups in the classroom; (3) varied materials used by individuals and small groups of students in the classroom; (4) variable pacing as a means of addressing learner needs; (5) knowledge centered; (6) learner centered (Tomlinson et al., 2003).

And then, Tomlinson and Strickland (2005) proposed five differentiated aspects, including: (1) Teaching content of the difference: in the textbooks, teachers can respond to students in varying degrees and needs; in the teaching method, it can be diverse. (2) Differences in the process, mainly through the group and the discussion. (3) Learning results differentiation: if students can be immersed in such a dynamic setting, they can feel freer to express their learning outcomes, that is, it encourages diversity of learning outcomes. (4) Differences in the teaching environment: teachers can create a classroom learning atmosphere to guide students. (5) Learning environment differentiation: teachers give students different space, different time, different teaching aids, and so on (Tomlinson, 2008).

Teachers implementing differentiated teaching can understand students' different learning styles, and can use different teaching materials, or teaching strategies to make the most effective student learning. Differentiated classrooms are learner-centered, knowledge-centered, assessment-centered, and community-centered (Coubergs, Struyven, Vanthournout, \& Engels, 2017; Tomlinson, 2015). 


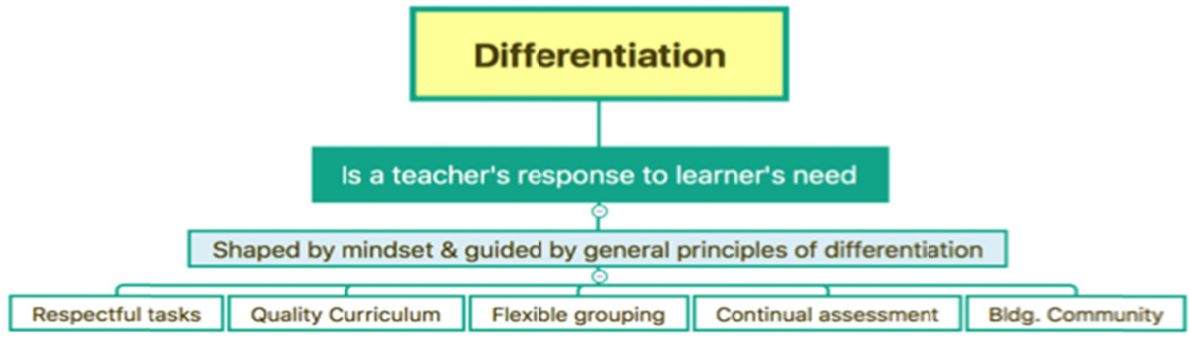

Teachers can differentiated through
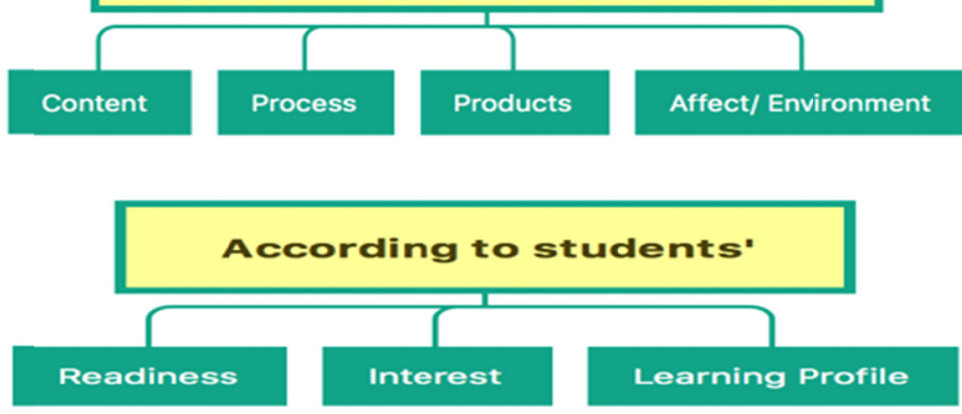

Through a variety of instructional strategies such as:

Graphic Organizers...Scaffolding Reading...Cubing...Think-

Tac-Toe...Learning Contracts... Tiering... Learning/Interest

Centers... Independent Studies....Intelligence

Preferences...Orbitals... Complex Instruction...4MAT...Web

Quests \& Web Inquiry...ETC.

Figure 1. Differentiated instruction flow chart from Tomlinson $(1999,2008)$

\subsection{Differentiated Instruction Research in Taiwan}

On June 21, 2017, a keyword "differentiated instruction" was used to search the National Central Library of National Digital Library of Theses and Dissertations in Taiwan, a total of 77 articles that cover 2012 to 2016. On June 21, 2015, a keyword "differentiated instruction" was used to search the National Central Library of PerioPath Index to Taiwan Periodical Literature System, a total of 43 scholastic articles that cover 2012 to 2016 (Figure 2).

From 2012 to 2016, for nearly five years or so, researchers in Taiwan began to focus on the study of differentiated instruction, mainly in the domains of elementary schools and junior high schools. Only one article was concerned with college students. This search showed the needs of differentiated instruction in college. In higher education, the methods of teaching, learning and thinking are also a matter of concern (Kroll, 2010). 


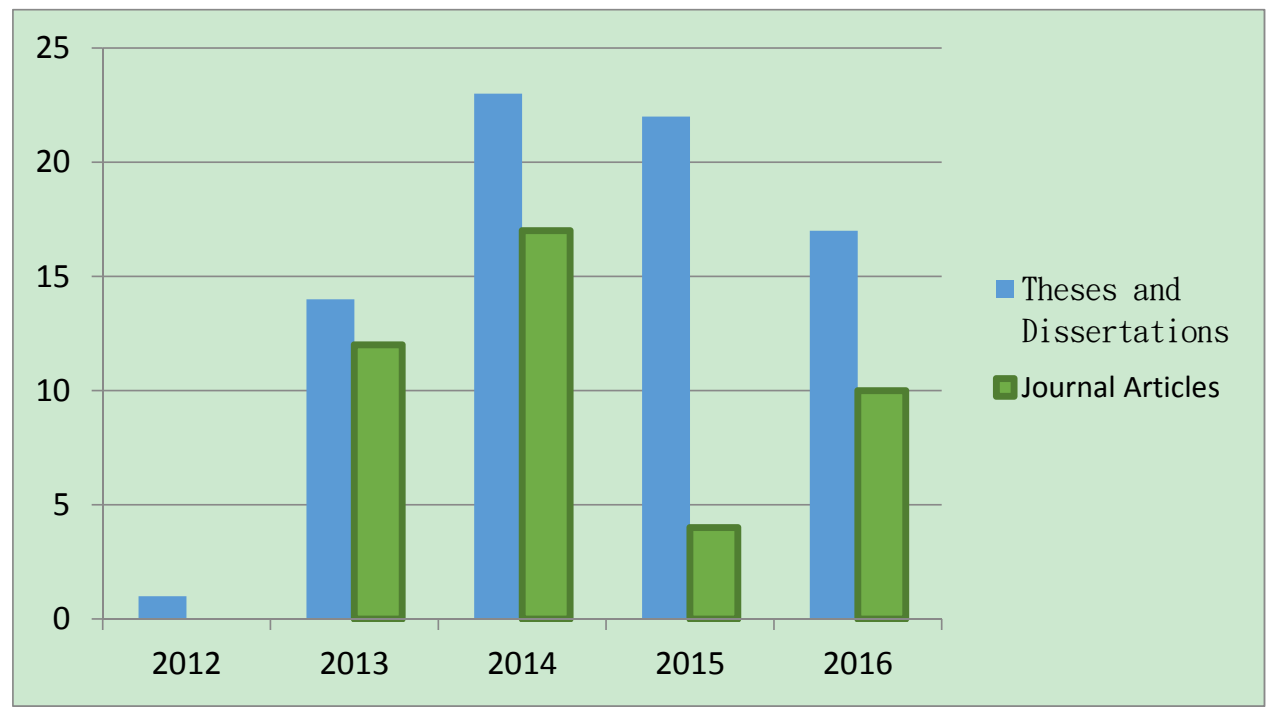

Figure 2. Comparison of differentiated instruction between the theses and dissertations, and scholastic articles, 2012-2016

Based on the above literature review, the aim of this study explores differentiation within the calculus curriculum to seek to understand the needs of college learners in Taiwan, learning difficulties, learning motivation and learning outcomes from the teaching process. The questions of this study are as follows:

1) What is the effect of differentiated instruction on the calculus curriculum?

2) How does the teacher in the classroom modify the teaching content and teaching process?

3) What is the feedback from the students?

\section{Method}

\subsection{Research Sample}

Sample data were collected from freshman students of the Army Academy, a total sample of 60 with a control group of 30 .

\subsection{Research Design}

The method used the "quasi-experimental design" of "non-equivalent control group design" (Table 1). Measurement of the dependent variable used the final exam score.

Table 1. Experimental design

\begin{tabular}{lccc}
\hline Group & Pre-test & Experimental treatment & Post-test \\
\hline Experimental group & 01 & $\mathrm{X} 1$ & 03 \\
Control group & 02 & & 04 \\
\hline
\end{tabular}

1) Pre-test: 01 02: Before the experimental treatment, the experimental group and the control group of participants were assessed with a test for the mathematical entry behavior test.

2) Experimental treatment: X1: Experimental group received the "calculus curriculum differentiated instruction for 16 weeks", over two hours once a week.

3) Post-test: 03 04: After the experimental treatment, participants in the experimental group and the control group were assessed with a test for the calculus final examination. 


\subsection{Research Procedure}

The aim of instruction is to have students to learn the basic definition of calculus, theories, and the problem-solving skills and methods. The traditional teaching method is the "teacher-centered" didactic instruction. Differentiated instruction on calculus curriculum is student-centered (Figure 2).

1) Grouping: the experimental group $(\mathrm{N}=30)$ was classified into 6 small groups; each group was 5 people. They drew random numbers to determine the order of the group competition. There were five levels of scores, which were $60,70,80,90$, and 100 as the general mark.

2) Teacher showed the example of 10 questions to students, first by grouping. Teacher circulated and observed each group, and the competition started 10 minutes later.

3) Groups drew random numbers to decide the order of the group competition; then the first group assigned one student to solve the problem, limited to 2 minutes, the audience could not prompt; and then the second group would be the next round, and so on.

4) A procedural chart of the contest appears in the Figure 3.

5) If the three groups were all wrong, then the last two groups with students who didn't join the group competition became the final contestants. Two students stood at the two sides of the blackboard, with the teacher in the middle of them. The teacher wrote a new math exercise. But if the two groups gave up at the same time, the teacher solved the problem and gave another new question, till a winner was produced. The winning group earned 100 and the loser received 90 points.

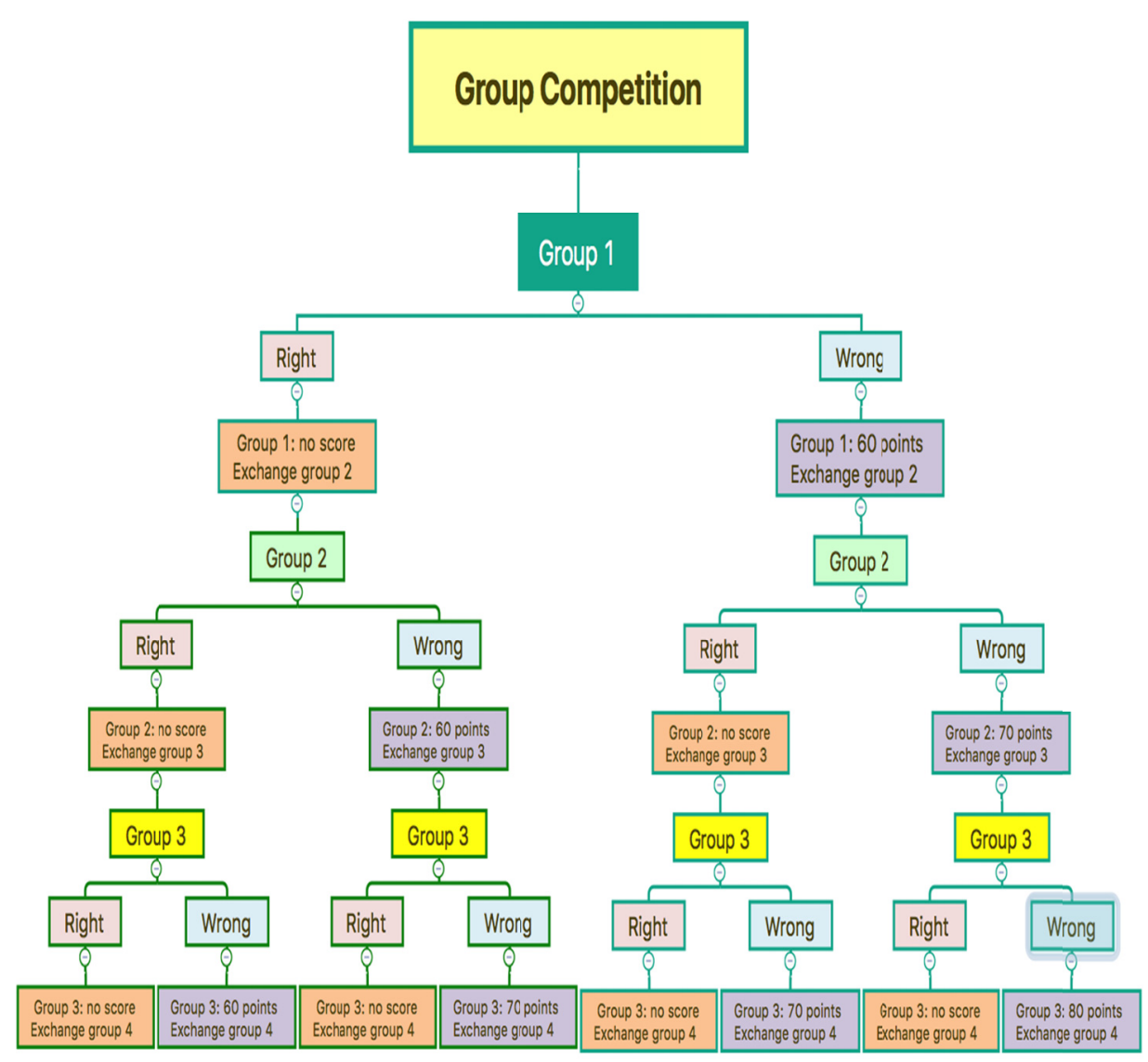

Figure 3. The Procedure of the group competition 


\subsection{Analysis Method}

All statistical procedures were conducted with SPPS (version 22). Research questions were checked before proceeding with the analysis. To answer the research questions, t-tests were applied. A significance level of $p$ $<.05$ was put forward.

\section{Results}

\subsection{The Pre-Test Outcomes}

The mathematical entry behavior test scores were analyzed statistically. The total sample size is 60 . The data showed pre-test scores for the experimental group $(\mathrm{M}=32.59, \mathrm{SD}=20.066)$ and control group $(\mathrm{M}=37.17, \mathrm{SD}$ $=21.99$ ). The independent-sample t-test, $\mathrm{t}(58)=-.862, p>.05$ (Table 2) indicated that the pre-test scores between experimental group and control group were not statistically significant. This meant that calculus ability between the two groups was consistent; thus, the follow-up study continued.

Table 2. The Pre-test score

\begin{tabular}{cccccccc}
\hline Group & $\mathrm{N}$ & mean & Standard Deviation & Standard Error & $\mathrm{df}$ & $\mathrm{t}$ & $\mathrm{p}$ \\
\hline Control & 30 & 37.17 & 21.999 & 4.016 & 58 & -.862 & .392 \\
Experimental & 30 & 32.59 & 20.066 & 3.862 & & & \\
\hline
\end{tabular}

$p>.05$.

\subsection{The Post-Test Outcomes}

The final exam test scores were analyzed statistically. The total sample size is 60 . Data revealed pre-test scores for the experimental group $(\mathrm{M}=51.70, \mathrm{SD}=29.596)$ and the control group $(\mathrm{M}=31.03, \mathrm{SD}=27.164)$ that were statistically significant. In Table $3, \mathrm{t}(58)=-2.818, p<.05$, indicates that differentiated instruction had a significant effect on how students scored after participating in the calculus program.

Table 3. The independent-sample T test about the post-test score of the calculus

\begin{tabular}{cccccccc}
\hline Group & $\mathrm{N}$ & mean & Standard Deviation & Standard Error & $\mathrm{df}$ & $\mathrm{t}$ & $\mathrm{P}$ \\
\hline Control & 30 & 31.03 & 27.164 & 4.959 & 58 & -2.818 & .007 \\
Experimental & 30 & 51.70 & 29.596 & 5.404 & & & \\
\hline
\end{tabular}

$* P<.05$.

\subsection{The Feedback}

Feedback was collected from the students at the final exam through an anonymous questionnaire, as follows:

1) Content: "The calculus curriculum has a lot of formula", "The course is rich in content", "The formula is very special", "We learned problem-solving skills", "The course is easy to understand", and so on.

2) Methods: "We like the mathematics competition", "Teaching method is very interesting", "Teacher explained the course vividly", "It is a very special way of examination", and so on.

3) Learning motivation: "We hope that the degree of mathematics becomes better", "We earnestly desire to learn calculus", "We would like to choose calculus-related courses", "We love the method that is applied by teacher", "We learned the steps to approach calculus and had a sense of accomplishment", "We desire to memorize the formula", "We understood and practiced more mathematics", "We increased mathematical abilities", "We earnestly practiced every exercise and put more time to practice", "In addition to finish homework, we also want to learn the relevant courses online", and so on.

4) Learning experience: "The test sheet is no longer blank", "We can pass mathematics exam and got a score of mathematics", "Calculus can train logic and thinking ability", "We understood the mystery of mathematics", and so on. 


\section{Discussion}

This study of differentiated instruction sought to understand whether differentiated instruction can enliven learning calculus. A quasi-experimental design tested for any difference between experimental group and control group. The experimental group had group competition and control group utilized the traditional teaching method. The results of the study clearly showed that the experimental group had a significant difference in their math test results compared with the control group. Differentiated instruction really improved the calculus learning results. In addition, feedback questionnaire data revealed that students loved the teaching content and differentiated teaching methods, the enhanced learning motivation, and student-shared learning experiences. Differentiated instruction improved mathematical achievement and learning motivation of college students, and improved teaching efficiency.

\subsection{Interest and Motivation}

Interest-based instruction is related to motivation and enhances the positive impacts on learning (Herbert, 1993; Tobias, 1994). Interest contributes to a learner's self-confidence and positive learning behavior, such as willingness to accept challenges and persist in it (Csikszentmihalyi et al., 1993; Fulk \& Montgomery-Grymes, 1994; Vallerand, Gagne, Senecal, \& Pelletier, 1994). And interest contributes to improve learning autonomy and generate higher levels of intrinsic motivation (Brunner, 1961).

Group competition in this study was helpful for improving students' motivation to learn. The process of group competition raises the interest of students participating in calculus. The grouping of the team can improve students' learning autonomy and thus enhance the intrinsic motivation. The student feedback questionnaire showed that differentiated teaching methods impressed the students quite well, and helped to enhance their will to learn.

\subsection{The Role of Teacher}

The experimental group is taught in a heterogeneous grouping of varied math ability, where instructors can observe the interaction between members and understand the needs of students through formative and summative assessment (Levy, 2008). After class, the teacher can target the individual needs of students and/or learning styles, individualized mathematics educational program, after which the instructors can do follow-up researches. Tomlinson et al. (2003) referred to the "Zone of Proximal Development (ZPD)", proposed by Vygotsky $(1978,1986)$, which means that when a child cannot successfully grasp the main points of an activity (Wood, Bruner, \& Ross, 1976), the teacher takes the role of social support. It is the teacher's job is to lead the child to the zone of proximal development, and within this range, learning through renewed study will take place magically.

\subsection{Limitations of the Study}

This study gathered information from college students, so results of the study may not be generalized to other groups. Future studies can be applied to primary schools, secondary schools, high schools, or others. Differentiated instructional methods may be developed within different school levels, with a view to meet the needs of each child as the goal.

\section{References}

Bearne, E. (Ed.). (1996). Differentiation and diversity in the primary school. London: Routledge.

Bruner, J. (1961). The act of discovery. Harvard Education Review, 31, 21-32.

Coubergs, C., Struyven, K., Vanthournout, G., \& Engels, N. (2017). Measuring teachers' perceptions about differentiated instruction: The DI-Quest instrument and model. Studies in Educational Evaluation, 53, 41-54. https://doi.org/10.1016/j.stueduc.2017.02.004

Csikszentmihalyi, M., Rathunde, K., \& Whalen, S. (1993). Talented teenagers: The roots of success and failure. New York: Cambridge University Press.

Fulk, B., \& Montgomery-Grymes, D. (1994). Strategies to improve student motivation. Intervention in School and Clinic, 30, 28-33. https://doi.org/10.1177/105345129403000105

Kroll, K. (2010). Contemplative practice in the classroom. New Directions for Community Colleges, 151, 111-113. https://doi.org/10.1002/cc.420

Levy, H. M. (2008). Meeting the needs of all students through differentiated instruction: Helping every child reach and exceed standards. The Clearing House: A Journal of Educational Strategies, 81(4), 161-164. https://doi.org/10.3200/TCHS.81.4.161-164 
Middendorf, C. (2009). Scholastic differentiated instruction plan book. Scranton PA. Scholastic: Teaching Resources.

Ministry of Education. (2015). The plan to promote 12-Year compulsory education. Retrieved from http://english.moe.gov.tw/ct.asp?xItem=7084\&ctNode $=784$

Stradling, B., \& Saunders, L. (1993). Differentiation in practice: Responding to the needs of all pupils. Educational Research, 35, 127-137. https://doi.org/10.1080/0013188930350202

Tobias, S. (1994). Interest, prior knowledge, and learning. Review of Educational Research, 64, 37-54. https://doi.org/10.3102/00346543064001037

Tomlinson, C. (1999). The differentiated classroom-responding to the needs of all learners. ASCD Product no. 108029.

Tomlinson, C. (2001). How to differentiate instruction in mixed-ability classrooms (2nd ed.). Alexandria, VA: Association for Supervision and Curriculum Development.

Tomlinson, C. (2008). Differentiation is NOT a set of strategies. It's a way of thinking about teaching and learning. Retrieved from http://www.caroltomlinson.com/2010SpringASCD/Rex_SA strategies.pdf

Tomlinson, C. A. (2015). Teaching for excellence in academically diverse classrooms. Society, 52(3), 203-209. https://doi.org/10.1007/s12115-015-9888-0

Tomlinson, C., \& Strickland, C. (2005). Differentiation in practice: A resource guide for differentiating curriculum, grade 9-12. ASCD Product no. 104140.

Tomlinson, C., Brighton, C., Hertberg, H., Callahan, C. M., Moon, T. R., Brimijoin, K., ... Reynolds, T. (2003). Differentiating instruction in response to student readiness, interest, and learning profile in academically diverse classrooms: A review of literature. Journal for the Education of the Gifted, 27(2-3), 119-145. https://doi.org/10.1177/016235320302700203

Vallerand, R., Gagne, F., Senecal, G., \& Pelletier, L. (1994). A comparison of the school intrinsic motivation and perceived competence of gifted and regular students. Gifted Child Quarterly, 36, 68-72. https://doi.org/10.1177/001698629403800403

Vygotsky, L. (1978). Mind in society. Cambridge, MA: Harvard University Press.

Vygotsky, L. (1986). Thought and language (A. Kozulin, Trans. \& Ed.). Cambridge, MA: MIT Press.

Wood, D., Bruner, J. S., \& Ross, G. (1976). The role of tutoring in problem solving. The Journal of Child Psychology and Psychiatry, 17(2), 89-100. https://doi.org/10.1111/j.1469-7610.1976. tb00381.x

$\mathrm{Wu}, \mathrm{Q}$. S. (2012). Differentiated instruction and students' learning. National Institute of Education Newsletter, 38. Retrieved from http://eaper.nare.edu.tw/epaper.php?edm_no $=38$

\section{Copyrights}

Copyright for this article is retained by the author(s), with first publication rights granted to the journal.

This is an open-access article distributed under the terms and conditions of the Creative Commons Attribution license (http://creativecommons.org/licenses/by/4.0/). 